\title{
Correction to: Myocardin regulates mitochondrial calcium homeostasis and prevents permeability transition
}

\author{
Wajihah Mughal ${ }^{1,2} \cdot$ Matthew Martens ${ }^{1,2} \cdot$ Jared Field $^{2,3} \cdot$ Donald Chapman $^{1,2} \cdot$ Jianhe Huang ${ }^{4} \cdot$ Sunil Rattan $^{5,6}$.

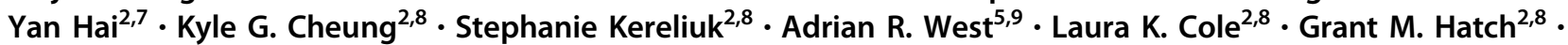 \\ William Diehl-Jones $^{3,10} \cdot$ Richard Keijzer $^{5,9,11} \cdot$ Vernon W. Dolinsky $^{2,8} \cdot$ Ian M. Dixon ${ }^{5,6} \cdot$ Michael S. Parmacek $^{4}$. \\ Joseph W. Gordon $\mathbb{D}^{1,2,7}$
}

Published online: 22 October 2019

(c) The Author(s) 2019. This article is published with open access

\section{Correction to: Cell Death \& Differentiation}

$$
\text { https://doi.org/10.1038/s41418-018-0073-z }
$$

The original PDF version of this article incorrectly showed the copyright holder to be 'ADMC Associazione Differenziamento e Morte Cellulare 2018', when the correct copyright holder is 'The Authors 2018'. This has been corrected in the PDF version of the article. The HTML version was correct from the time of publication.

Edited by L. Scorrano

$\triangle$ Joseph W. Gordon

joseph.gordon@umanitoba.ca

1 Department of Human Anatomy and Cell Science, University of Manitoba, Winnipeg, MB, Canada

2 Diabetes Research Envisioned and Accomplished in Manitoba (DREAM) Theme, Children's Hospital Research Institute of Manitoba, Winnipeg, MB, Canada

3 Department of Biological Science, University of Manitoba, Winnipeg, MB, Canada

4 Department of Medicine, Penn Cardiovascular Institute, Hospital of the University of Pennsylvania, Philadelphia, PA, USA

5 Department of Physiology and Pathophysiology, University of Manitoba, Winnipeg, MB, Canada
Open Access This article is licensed under a Creative Commons Attribution 4.0 International License, which permits use, sharing, adaptation, distribution and reproduction in any medium or format, as long as you give appropriate credit to the original author(s) and the source, provide a link to the Creative Commons license, and indicate if changes were made. The images or other third party material in this article are included in the articleâ€ $\mathrm{TM}_{\mathrm{S}}$ Creative Commons license, unless indicated otherwise in a credit line to the material. If material is not included in the articleâ $\mathfrak{f M}^{\mathrm{TM}}$ Creative Commons license and your intended use is not permitted by statutory regulation or exceeds the permitted use, you will need to obtain permission directly from the copyright holder. To view a copy of this license, visit http://crea tivecommons.org/licenses/by/4.0/.
6 Institute of Cardiovascular Sciences, St. Boniface Research Centre, Winnipeg, MB, Canada

7 College of Nursing, University of Manitoba, Winnipeg, MB, Canada

8 Department of Pharmacology and Therapeutics, University of Manitoba, Winnipeg, MB, Canada

9 The Biology of Breathing Theme, Children's Hospital Research Institute of Manitoba, Winnipeg, MB, Canada

10 Faculty of Health Disciplines, Athabasca University, Edmonton, MB, Canada

11 Department of Surgery, University of Manitoba, Winnipeg, MB, Canada 